\title{
Transmisi Harga Beras Di Indonesia: Pendekatan Threshold Cointegration
}

\section{Rice Price Transmission In Indonesia: Threshold Cointegration Approach}

\section{Deby Ananda Difah ${ }^{1}$, Harianto ${ }^{2}$, dan Dedi Budiman Hakim²}

${ }^{1}$ Post Graduate Student of Agricultural Economics, Bogor Agricultural University, Indonesia

${ }^{2}$ Faculty of Economics and Management, Bogor Agricultural University, Indonesia

Corresponding author: debyad8@gmail.com

\begin{abstract}
Rice is a staple food that is still a top priority for most of Indonesian. The widening difference between the rice price at the farmer level and the retail price of rice indicates the presence of asymmetric vertical price transmission. A stable and affordable price is one of the important components needed to maintain food distribution. The price of food commodities that fluctuate too much can be relied upon by farmers as producers, processors, traders to consumers, and about social unrest. To maintain stability of staple food prices, the government is open to keep rice prices at a certain level that can benefit farmers and consumers alike. This research used Threshold Vector Error Correction Model (TVECM) to estimate threshold value and to analyze rice price transmission relationship at farm level and retail level. The data used monthly time series data from January 1990 to September 2016. The results show that the estimated threshold value obtained is -0.092. This suggests that when the deviation of retail price and farmers in long-term equilibrium exceeds 9.2 percentage, the price of retail rice will adjust to achieve its equilibrium so that the two rice prices have a cointegration relationship. Conversely, when the deviation of rice prices is less than 9.2 percentage, there will be no price adjustment and no market integration. The price of retail rice has increased faster than the price at the farm level.
\end{abstract}

Keywords: rice, cointegration, threshold, price transmission,

Disubmit : 15 Agustus 2019, Diterima: 10 September 2019, Disetujui : 17 Oktober 2019

\section{PENDAHULUAN}

Beras merupakan bahan pangan pokok yang masih tetap mendapat prioritas utama untuk memenuhi kebutuhan konsumsi sebagian besar penduduk Indonesia. Menurut Dodge E (2012) berdasarkan data Susenas tahun 2010, sebanyak 98.5 persen masyarakat Indonesia mengkonsumsi beras sebagai bahan pangan pokoknya. Masyarakat Indonesia yang mencapai 252.17 juta orang dengan laju pertumbuhan sebesar 1.31 persen memiliki tingkat konsumsi beras mencapai 132.98 kg/kapita/tahun (Pusdatin 2015). Negara-negara di Asia masih mendominasi dalam bidang produksi, konsumsi dan perdagangan beras dunia. Indonesia merupakan negara penghasil beras ke tiga terbesar di dunia dengan mengambil pangsa sebesar 7.65 persen dari total produksi beras dunia setelah China (29.98 persen) dan India (22.33 persen). Indonesia juga berada diposisi tiga sebagai konsumen terbesar dunia dengan mengambil pangsa sebesar 7.84 persen dari total konsumsi beras dunia setelah China (29.96 persen) dan India (20.32 persen) (USDA 2017). 


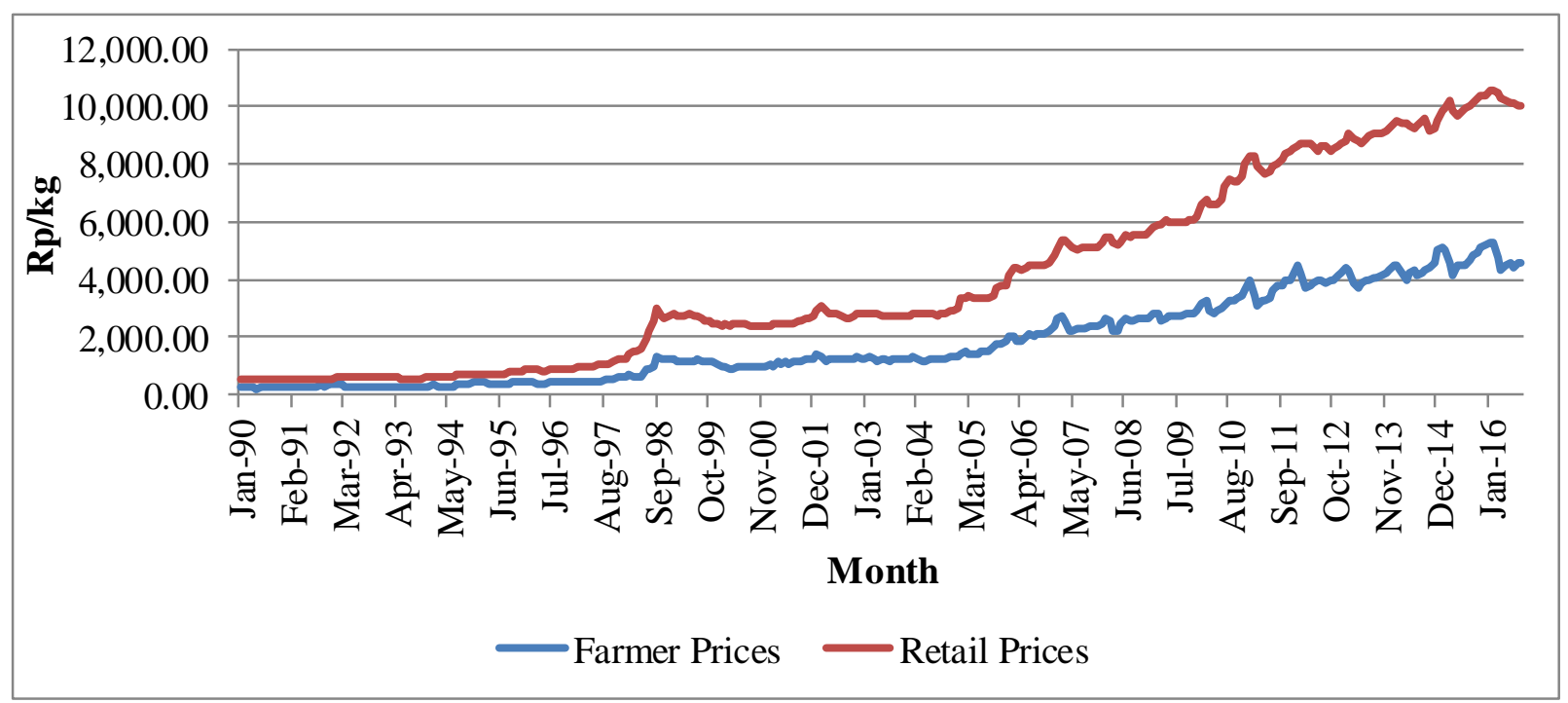

Sumber: BULOG (2016). (Diolah)

Gambar 1 Perkembangan harga beras di tingkat petani dan harga beras di tingkat eceran pada bulan Januari 1990 hingga September 2016

Beras menjadi komoditas politik dan strategis, sehingga pemerintah menetapkan kebijakan strategis untuk mengatur beras agar memastikan semua orang memiliki akses makanan sebagai kebutuhan standar (Fitriani, 2017). Kebijakan harga beras oleh pemerintah merupakan salah satu instrumen penting untuk menjaga stabilitas pasokan beras. Harga menjadi salah satu indikator untuk melihat tingkat efisiensi dari rantai pemasaran pada suatu komoditi. Pada Gambar 1 menunjukkan bahwa harga beras domestik di tingkat petani dan eceran periode Januari 1990 sampai Desember 1997 cenderung stabil, yaitu pada rata-rata Rp 357.22 per kg untuk gabah dan Rp 706.63 per kg untuk beras. Namun pada periode berikutnya, harga beras eceran terus meningkat secara signifikan, dari Rp 1290.04 per kg pada Januari 1998 menjadi Rp 3009.71 per kg pada September 1998 (atau meningkat sebesar 133.30 persen), bahkan kemudian menjadi Rp 10 082.00 per kg pada September 2016 (atau meningkat sebesar 235.45 persen). Hal yang sama juga terjadi pada harga Gabah Kering Panen (GKP) di tingkat petani. Harga GKP meningkat sebesar 101.69 persen dari Rp 653.00 per kg pada Januari 1998 menjadi Rp 1317.00 per kg pada September 1998, kemudian meningkat sebesar 250.87 persen menjadi Rp 4621.00 per kg pada September 2016. Besarnya perbedaan harga di tingkat petani dan konsumen selama periode tahun 1998 hingga tahun 2016 mencerminkan bahwa pergerakan harga beras di tingkat petani tidak ditransmisikan secara sempurna terhadap harga beras di tingkat konsumen, ataupun sebaliknya.

Berdasarkan Gambar 1 dapat dilihat bahwa harga beras di tingkat petani dan harga di tingkat eceran pada periode 1990-1997 relatif stabil. Memasuki tahun 1998 harga di kedua tingkat tersebut mulai menunjukkan kecenderungan terjadinya kenaikan harga. Harga beras eceran mengalami kenaikan sebesar 133.30 persen dari Rp 1.290,04 per kg pada Januari 1998 menjadi Rp 3.008,71 per kg pada September 1998. Sedangkan harga beras di tingkat petani mengalami kenaikan sebesar 101.69 persen dari Rp 653,00 per kg pada Januari 1998 menjadi Rp 1.317,00 per kg pada September 1998. Memasuki periode tahun 2000-2004 harga beras di tingkat petani dan di tingkat eceran kembali relatif stabil, meskipun disparitas kedua harga mulai meningkat. Sejak memasuki tahun 2005, fluktuasi harga relatif tinggi dan disparitas harga beras di tingkat petani dan eceran semakin melebar.

Menurut Sawit (2014) ada dua faktor yang menentukan besarnya disparitas harga beras di tingkat petani dan eceeran, yaitu biaya pengolahan gabah menjadi beras yang semakin tinggi dan margin pemasaran beras yang semakin kurang efisien. Selain itu menurut Yuningsih (2012) disparitas tersebut juga disebabkan 
oleh perubahan kebijakan impor yang terjadi di tahun 2004. Pada tahun 2004, pemerintah mengeluarkan SK Menperindag No. 9/MPP/Kep/1/2004 tentang ketentuan impor beras yang diantaranya mengatur mengenai waktu impor beras dan pihak yang dapat menjadi importir beras. Kebijakan tersebut cukup efektif dalam meningkatkan harga beras di tingkat petani. Namun, kebijakan tersebut juga memberikan efek peningkatan terhadap harga beras di tingkat eceran. Berdasarkan Gambar 1 kenaikan harga beras di tingkat eceran jauh lebih tinggi dibandingkan kenaikan harga yang terjadi di tingkat petani. Hal tersebut mengindikasikan bahwa harga di tingkat petani dan eceran tidak ditransmisikan secara sempurna.

Keadaan perbedaan harga beras di tingkat petani dan eceran yang semakin melebar mengindikasikan bahwa terjadinya fenomena transmisi harga vertikal yang tidak simetris (asimetris). Transmisi harga dikatakan tidak simetris apabila terdapat perbedaan respon harga antara saat terjadi kenaikan harga (shock harga positif) dengan saat terjadi penurunan harga (shock harga negatif). Menurut Vavra and Goodwin, (2005), salah satu penyebab transmisi harga yang tidak simetris antar pasar yang terhubung secara vertikal (dalam satu rantai pemasaran) adalah adanya perilaku tidak kompetitif antara para pedagang perantara, khususnya apabila pedagang perantara tersebut berada pada pasar yang terkonsentrasi. Umumnya pedagang perantara akan berusaha mempertahankan tingkat keuntungannya dan tidak akan menaikkan atau menurunkan harga sesuai dengan sinyal harga yang sebenarnya. Sehingga pedagang perantara akan lebih cepat bereaksi terhadap kenaikan harga dibandingkan dengan penurunan harga. Selain itu kekakuan dalam proses penyesuaian harga antar level dalam satu rantai pemasaran sering pula disebabkan adanya sejumlah tambahan biaya yang harus dikeluarkan oleh pelaku usaha untuk menyesuaikan harganya atau yang biasa disebut dengan adjustment cost/menu cost.

Semakin penting untuk memahami sejauh mana guncangan harga di konsumen dapat ditransmisikan kepada petani ataupun sebaliknya. Struktur pasar, pola perdagangan, dan pemicu transmisi guncangan harga tersebut menjadi faktor yang penting dalam penentuan kebijakan dalam proses stabilitas harga pangan. Penelitian ini akan menggunakan pendekatan dengan pemodelan TVECM (Threshold Vector Error Correction Model) yang merupakan pola tertentu dari Error Correction Model dimana penyimpangan dari hubungan harga ekuilibrium jangka panjang hanya menginduksi harga jika harga tersebut melebihi ambang batas tertentu. Oleh karena itu, TVECM memungkinkan keberadaan kumpulan kombinasi harga pasif yang tidak ada respon terhadap penyimpangan dari keseimbangan jangka panjang serta digunakan untuk memperkirakan transmisi harga yang tidak simetris (Aprilia, 2014). Pemodelan TVECM merupakan pendekatan dengan membagi deret waktu menjadi beberapa daerah pembagian (regimes) yang dipisahkan oleh threshold. Threshold merupakan suatu titik belok di mana pada titik tersebut terjadi pergantian kelinieran model. Model TVECM dengan satu buah threshold membagi deret waktu menjadi dua buah regimes. Data harga beras dalam kurun waktu beberapa tahun terakhir ini menunjukkan pola yang fluktuatif dan cenderung memiliki pola nonlinier. Untuk mengamati pola nonlinier yang sangat fluktuatif, maka pada penelitian ini model TVECM dengan threshold tunggal. Untuk meningkatkan efektivitas kebijakan dan program stabilisasi harga pangan dibutuhkan informasi yang lengkap mengenai perilaku harga komoditas beras. Mengacu pada kompleksitas masalah harga beras, tujuan penelitian ini adalah mestimasi nilai threshold serta menganalisis transmisi harga beras di tingkat petani dan di tingkat eceran.

\section{METODE PENELITIAN}

Data yang digunakan dalam penelitian ini adalah data sekunder dalam bentuk data deret waktu (time series) bulanan dengan periode waktu bulan Januari 1990 hingga bulan September 2016. Jenis data bulanan yang dikumpulkan berupa harga beras di tingkat petani dan harga beras di tingkat eceran, dan Indeks Harga Konsumen (IHK). Sumber data Adapun jenis data yang digunakan beserta besaran dan sumbernya disajikan pada Tabel 1: 
Tabel 1 Jenis dan sumber data yang digunakan dalam penelitian

\begin{tabular}{cllc}
\hline No. & \multicolumn{1}{c}{ Data } & Satuan & Sumber \\
\hline 1. & Harga beras di tingkat eceran (domestik) & $\mathrm{Rp} / \mathrm{kg}$ & Perum BULOG \\
2. & Harga beras di tingkat petani (GKP) & $\mathrm{Rp} / \mathrm{kg}$ & Perum BULOG \\
3. & $\begin{array}{l}\text { Indeks Harga Konsumen } \\
\text { (tahun dasar 2012=100) }\end{array}$ & & $\begin{array}{c}\text { International Monetary } \\
\text { Fund (IMF) }\end{array}$ \\
\hline
\end{tabular}

Pengolahan data pada analisis ini digunakan software Eviews 7.0 dan R.3.3.3. Terdapat beberapa langkah prosedur yang diterapkan dalam analisis ini, diantaranya adalah sebagai berikut:

Uji Stasioneritas

Uji stasioneritas data ini dapat dilakukan dengan menggunakan Augmented Dickey-Fuller (ADF) pada derajat yang sama (level atau different) hingga diperoleh suatu data yang stasioner. Uji ADF menggunakan persaman sebagai berikut:

$$
\mathrm{P}_{\mathrm{t}}=\alpha_{0}+\gamma \mathrm{P}_{\mathrm{t}-1}+\sum_{i=1}^{p} \beta_{i} \Delta \psi_{t-i}+\mathrm{t}
$$

Keterangan:

$\mathrm{P}_{\mathrm{t}} \quad=$ variabel harga beras (di tingkat petani dan eceran) pada periode $\mathrm{t}(\mathrm{Rp} / \mathrm{kg})$

$\mathrm{P}_{\mathrm{t}-1} \quad=$ variabel harga beras pada periode sebelumnya $(\mathrm{Rp} / \mathrm{kg})$

$\mathrm{P}_{\mathrm{t}-\mathrm{i}} \quad=$ variabel harga beras pada periode $\mathrm{t}$ dikurangi nilai lag $(\mathrm{Rp} / \mathrm{kg})$

$\mathrm{P}_{\mathrm{t}} \quad=\mathrm{P}_{\mathrm{t}}-\mathrm{P}_{\mathrm{t}-1}$

$\mathrm{p} \quad=$ jumlah lag yang digunakan dalam model

$\alpha_{0} \quad=$ intersep

$\gamma, \beta \quad=$ koefisien parameter

$\mathrm{t} \quad=$ error term

Hipotesis yang digunakan adalah:

$\mathrm{H}_{0}: \gamma=0$ (yang berarti $\mathrm{P}_{\mathrm{t}}$ bersifat tidak stasioner)

$\mathrm{H}_{1}: \gamma<0$ (yang berarti $\mathrm{P}_{\mathrm{t}}$ bersifat stasioner)

Penentuan Lag Optimal

Dalam penentuan lag optimal dengan menggunakan kriteria informasi tersebut, kriteria yang dipilih adalah kriteria yang mempunyai jumlah dari Akaike Information Criterion (AIC) dan SC Schwarz Information Criterion (SC) yang paling kecil di antara berbagai lag yang dianjurkan. Bila semakin kecil nilai kriteria tersebut, maka nilai harapan yang dihasilkan oleh sebuah model akan semakin mendekati kenyataan. Sedangkan jika beberapa kriteria tersebut digunakan maka ada kriteria tambahan yaitu adjusted $\mathrm{R} 2$ sistem VAR. Panjang kelambanan optimal terjadi jika nilai adjusted $\mathrm{R}^{2}$ adalah paling tinggi (Widarjono, 2013).

Uji Kointegrasi

Pengujian kointegrasi pada penelitian ini dilakukan untuk menunjukkan hubungan jangka panjang antara variabel harga beras di tingkat petani dan eceran. Model pengujian kointegrasi yang digunakan maximum likelihood (Vavra dan Goodwin, 2005).

Berdasarkan metode Johansen, uji kointegrasi diawali dengan model VAR tradisional untuk menentukan jumlah lag yang optimal, berdasarkan uji likelihood ratio. Lag optimal tersebut digunakan untuk mengestimasi VECM dan menentukan peringkat dari matriks parameter. Persamaan kointegrasi model VECM adalah sebagai berikut:

$$
\mathrm{P}_{\mathrm{t}}=\Pi_{\mathrm{P}-1}+\Gamma_{1} \quad \mathrm{P}_{\mathrm{t}-1}+\ldots . .+\Gamma_{\mathrm{k}-1} \quad \mathrm{P}_{\mathrm{t}-\mathrm{k}+1}+\mathrm{t}_{\mathrm{t}}
$$

Keterangan:

$\mathrm{P}_{\mathrm{t}} \quad=$ vektor dari variabel harga $\mathrm{I}(1)$

$=$ vektor dari error term 
$\Gamma_{1} \quad=$ menunjukkan dinamika jangka pendek dari data harga

$\Pi \quad=$ menunjukkan informasi hubungan kointegrasi antara dua variabel

Berdasarkan metode Johansen, VECM diestimasi menggunakan maximum likelihood $\mathrm{L}_{\max }(\mathrm{r}$ ) yang merupakan fungsi dari peringkat kointegrasi $\mathrm{r}$. Untuk menguji adanya hubungan jangka panjang antar variabel, terdapat dua metode pengujian yaitu trace test dan maximum eigenvalue test. Apabila nilai trace statistic (TS) dan maximal eigenvalue (ME) melebihi nilai t-statistik maka hipotesis nol ditolak. Dengan kata lain terdapat hubungan jangka panjang antara variabel-variabel yang dianalisa. Pengujian TS dan ME mengikuti persamaan berikut:

$$
\begin{aligned}
& \lambda_{\text {trace }}=-\mathrm{T} \Sigma \ln \left(1-\hat{\gamma}_{\mathrm{i}}\right) \\
& \lambda_{\max }(\mathrm{r}, \mathrm{r}+1)=-\mathrm{T} \Sigma \ln \left(1-\hat{\gamma}_{\mathrm{r}+1}\right)
\end{aligned}
$$

Keterangan:

$\hat{\gamma}_{\mathrm{i}} \quad=$ nilai dugaan akar karakteristik (eigenvalues) yang didapatkan dari estimasi matriks $\Pi$

$\mathrm{T} \quad=$ jumlah observasi

$\mathrm{r} \quad=$ pangkat yang mengindikasikan jumlah vektor kointegrasi

Threshold Vector Error Correction Model (TVECM)

Analisis integrasi pasar sesuai dengan data harga saja telah dikritik karena mereka mengabaikan biaya transaksi. TVECM dapat menjelaskan efek dari biaya transaksi dalam transmisi harga tanpa secara langsung tergantung pada informasi mengenai biaya-biaya tersebut. Threshold cointegration diusulkan oleh (Fomby dan Blake (1997) sebagai teknik yang layak untuk menggabungkan non-linearitas dan kointegrasi. Secara khusus, model ini memungkinkan untuk penyesuaian non-linear menuju ekuilibrium jangka panjang.

Model threshold digunakan untuk mengeksplorasi dan penyesuaian kecepatan transmisi harga serta pendekatan kointegrasi digunakan untuk mengetahui apakah terjadi integrasi dalam jangka panjang atau tidak. Fomby and Blake (1997) memperkenalkan Threshold cointegration yang menggabungkan kenonlinieran dan kointegrasi dengan memungkinkan penyesuaian nonlinier dalam jangka panjang (nonlinear adjustments over the long run). Threshold Vector Error Correction Model (TVECM) adalah suatu model yang digunakan untuk mengetahui suatu kondisi yang dibatasi ambang batas (threshold), sehingga tercipta dua atau lebih kondisi yang berbeda. Perluasan model ini meningkatkan kemampuan analisis kointegrasi untuk merepresentasikan fenomena ekonomi dunia nyata dengan melonggarkan asumsi bahwa kecepatan di mana seri terkointegrasi bergerak ke arah hubungan keseimbangan jangka panjang tidak konstan dari waktu ke waktu. TVECM juga digunakan untuk memperkirakan transmisi harga yang tidak simetris. Fomby and Blake (1997), menyatakan bahwa model threshold adalah model keseimbangan ekonomi dinamis yang lebih tepat untuk menguji hubungan harga yang dinamis antara pasar yang berbeda.

Hansen and Seo (2002) mengestimasi dua regime Threshold Vector Error Correction Model (TVECM) dengan satu kointegrasi vektor dan parameter threshold berdasarkan error correction term. Persaamaan sebuah TVECM dapat dinyatakan sebagai berikut:

$$
\Delta P_{t}= \begin{cases}\alpha^{1} \omega_{\tau-1}(\beta)+\sum_{t=1}^{k-1} r_{l}^{1} \Delta P_{l-1}+u_{t}^{1} & \text { if } \omega_{\tau-1}(\beta) \leq \gamma \\ u^{2} \omega_{\tau-1}(\beta)+\sum_{L=1}^{k-1} r_{l}^{2} \Delta P_{t-1}+u_{\tau}^{2} & \text { if } \omega_{\tau-1}(\beta)>\gamma\end{cases}
$$

Persamaan (5) dapat dijabarkan sebagai berikut: 


$$
\begin{aligned}
& \left.\Delta P R_{t}=\theta_{11}+\alpha^{1} \omega_{t-1}(\beta)+\lambda^{1}{ }_{111} \Delta P R_{t-1}+\lambda^{1}{ }_{1<1} \Delta P F_{t-1}\right)
\end{aligned}
$$

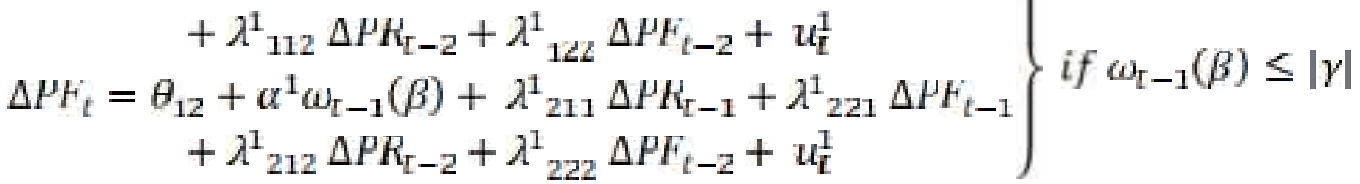

$$
\begin{aligned}
& \left.\Delta P K_{t}=\theta_{21}+u^{2} \omega_{t-1}(\beta)+\lambda^{2}{ }_{111} \Delta P K_{t-1}+\lambda^{2}{ }_{121} \Delta P F_{t-1}\right) \\
& +\lambda^{2}{ }_{11 L} \Delta P R_{[-2}+\lambda^{2}{ }_{12 L} \Delta P F_{t-L}+u_{t}^{2}
\end{aligned}
$$



Keterangan:

$\mathrm{PR}_{\mathrm{t}} \quad=$ retail prices

$\mathrm{PF}_{\mathrm{t}} \quad=$ farmer prices

$\omega_{\mathrm{t}-1}(\beta)=$ residual dari hubungan keseimbangan harga beras di tingkat eceran-petani yang mewakili variabel threshold (ECT)

$\gamma \quad=$ parameter threshold yang memisahkan dua regime

\section{HASIL DAN PEMBAHASAN}

\section{Uji Stasioneritas}

Pengujian stasioneritas data dalam penelitian ini menggunakan Augmented Dickey Fuller (ADF) seperti yang terlihat pada Tabel 2. Hasil uji ADF untuk harga gabah dan beras eceran menunjukkan bahwa data harga yang dianalisis menggunakan kriteria intersep tanpa tren adalah stasioner pada first difference pada ujii ADF. Semua variabel harga yaitu harga beras di tingkat petani dan harga beras di tingkat eceran yang digunakan stasioner pada taraf nyata satu persen. Hal ini ditunjukkan dengan nilai probabilitasnya yang kurang dari taraf signifikansinya pada uji ADF maupun PP sehingga $\mathrm{H}_{0}$ ditolak, yang artinya data tidak mengalami unit root atau data stasioner pada first difference.

Tabel 2 Hasil uji stasioneritas data

\begin{tabular}{ccc}
\hline Variabel & ADF & \\
\cline { 2 - 3 } & Level & First Difference \\
\hline Harga Beras di Tingkat Petani (lnPF) & -1.490 & -3.977 \\
& {$[0.529]$} & {$[0.002]^{*}$} \\
Harga Beras di Tingkat Eceran (lnPR) & $-1.010[0.707]$ & -13.887 \\
\hline
\end{tabular}

Keterangan: *stasioner pada taraf $1 \%, * *$ stasioner pada taraf $5 \%$,

*** stasioner pada taraf $10 \%$

\section{Uji Kointegrasi}

Kandidat lag optimum yang akan dicari dengan menggunakan kriteria informasi yang tersedia yaitu kriteria Likehood Ratio (LR), Final Prediction Error (FPE), Akaike Information Criterion (AIC), Shwarz Information Criterion (SC), dan Hannan-Quin Criterion (HQ). Apabila kriteria informasi menunjuk pada sebuah kandidat lag, maka lag tersebut yang akan dipilih untuk melanjutkan estimasi pada tahap berikutnya. Berdasarkan pada Tabel 3 diperoleh hasil bahwa dalam penelitian ini digunakan kriteria SC dan HQ, yang menunjukkan bahwa lag optimal yang akan digunakan adalah lag dua. 
Difa Deby Ananda dkk : Transmisi Harga Beras Di Indonesia: Pendekatan Threshold Cointegration.......

Tabel 3 Penentuan lag optimal harga beras domestik dan harga dunia

\begin{tabular}{cccccc}
\hline No. & LR & FPE & AIC & SC & HQ \\
\hline 0 & NA & 0.000404 & -2.138754 & -2.114704 & -2.129141 \\
1 & 1787.702 & $1.25 \mathrm{e}-06$ & -7.917257 & -7.845107 & -7.888417 \\
2 & 30.66933 & $1.16 \mathrm{e}-06$ & -7.991760 & $-7.871509^{*}$ & $-7.943694^{*}$ \\
3 & 11.41817 & $1.15 \mathrm{e}-06$ & -8.003596 & -7.835246 & -7.936304 \\
4 & 6.317129 & $1.15 \mathrm{e}-06$ & -7.998791 & -7.782339 & -7.912272 \\
5 & 11.67206 & $1.14 \mathrm{e}-06$ & -8.011974 & -7.747423 & -7.906229 \\
6 & 6.215281 & $1.14 \mathrm{e}-06$ & -8.007107 & -7.694456 & -7.882136 \\
7 & 12.99914 & $1.12 \mathrm{e}-06$ & -8.025300 & -7.664548 & -7.881102 \\
8 & 5.452333 & $1.13 \mathrm{e}-06$ & -8.018122 & -7.609270 & -7.854698 \\
9 & 12.31539 & $1.11 \mathrm{e}-06$ & -8.034574 & -7.577622 & -7.851924 \\
10 & $14.54236^{*}$ & $1.08 \mathrm{e}-06^{*}$ & $-8.058997^{*}$ & -7.553944 & -7.857120 \\
\hline
\end{tabular}

Keterangan: *indicates lag order selected by the criterion

Setelah dilakukan pengujian stasioneritas data dan penentuan lag optimal, selanjutnya yakni pengujian kointegrasi. Pengujian kointegrasi dalam penelitian ini menggunakan pendekatan uji Johansen. Uji Johansen dalam penelitian ini dilakukan dengan membandingkan antara nilai trace statistic dengan nilai critical value dan maximum eigenvalue dengan critical value pada taraf nyata lima persen. Jika trace statistic atau maximum eigenvalue lebih besar dari critical value maka mengindikasikan bahwa dalam system persamaan terdapat hubungan jangka panjang atau kointegrasi. Hasil pengujian kointegrasi Johansen dapat dilihat pada Tabel 4.

Tabel 4 Hasil uji kointegrasi Johansen

\begin{tabular}{ccccc}
\hline Hipotesis & Trace Statistic & Critical Value & Max-Eigen Statistic & Critical Value \\
& & $\mathbf{5 \%}$ & $\mathbf{5 \%}$ \\
\hline None & 27.819 & 15.495 & 26.947 & 14.265 \\
At most 1 & 0.872 & 3.841 & 0.872 & 3.841 \\
\hline
\end{tabular}

Berdasarkan Tabel 4 dapat diketahui bahwa terdapat hubungan kointegrasi antara pasar beras di tingkat petani dengan pasar beras di tingkat eceran. Hal ini ditunjukkan oleh nilai trace statistic dan maximum eigenvalue sebesar 27.819 dan 26.947 pada tingkat signifikansi lima persen yang menunjukkan bahwa memiliki hubungan keseimbangan jangka panjang. Dengan demikian terdapat satu persamaan yang dapat dijelaskan adanya hubungan kointegrasi pada variabel-variabel dalam model.

Threshold Vector Error Correction Model pada Harga Beras di Tingkat Petani dan Eceran

Pengujian Threshold Vector Error Correction Model (TVECM) dilakukan berdasarkan pendekatan yang dilakukan oleh Hansen dan Seo (2002), hasil pengujian ini disajikan pada Tabel 5.

Tabel 5 Hasil estimasi TVECM

\begin{tabular}{|c|c|c|c|c|}
\hline \multicolumn{5}{|c|}{ Threshold VECM } \\
\hline \multirow{2}{*}{ Koefisien } & \multicolumn{2}{|c|}{ First Regime $(6.3 \%)$} & \multicolumn{2}{|c|}{ Second Regime $(93.7 \%)$} \\
\hline & $\Delta \mathrm{nPF}_{\mathrm{t}}$ & $\Delta n P R_{t}$ & $\Delta \mathrm{nPF}_{\mathrm{t}}$ & $\Delta n P R_{t}$ \\
\hline (R) & 0.240 & 0.224 & -0.166 & 0.022 \\
\hline$w_{i-1}(1 / P)$ & $(0.509)$ & $(0.125)$ & $(0.001)^{*}$ & $(0.266)$ \\
\hline$\Delta \mathrm{nPF}_{\mathrm{t}-1}$ & $\begin{array}{c}0.384 \\
(0.250)\end{array}$ & $\begin{array}{c}0.312 \\
(0.020) * *\end{array}$ & $\begin{array}{c}0.172 \\
(0.010)^{*}\end{array}$ & $\begin{array}{c}0.052 \\
(0.052) * *\end{array}$ \\
\hline
\end{tabular}

Volume 3, Nomor 2,Tahun 2019 Hal 37 


\begin{tabular}{lcccc}
\hline $\boldsymbol{\Delta}$ nnPF $\mathbf{F}_{\text {-2 }}$ & -0.455 & -0.346 & -0.086 & 0.044 \\
& $(0.037)^{* *}$ & $\left(8.6 \times 10^{-5}\right)$ & $(0.210)$ & $(0.114)$ \\
$\boldsymbol{N n P R}_{\mathbf{t}-1}$ & 1.138 & 0.803 & -0.012 & 0.126 \\
& $(0.032)^{* *}$ & $(0.000)^{*}$ & $(0.941)$ & $(0.056)$ \\
$\boldsymbol{N}_{\mathbf{n P R}}$ & 1.822 & 1.034 & -0.301 & -0.136 \\
& $(0.016)^{* *}$ & $(0.001)^{*}$ & $(0.055)^{* * *}$ & $(0.030)^{* *}$ \\
Intercept & 0.080 & 0.0427 & 0.006 & 0.000 \\
& $(0.092)^{* * *}$ & $(0.026)^{* *}$ & $(0.117)$ & $(0.897)$ \\
\hline
\end{tabular}

Threshold E stimate ( ()$\quad-0.092$

$\begin{array}{ll}\text { SupLM } & \text { Test statistic value: } 28.256 \\ & \text { Fixed Regressor } p \text {-value: } 0.016 * *\end{array}$

TVECM dalam penelitian ini menggunakan satu threshold yang membagi model menjadi dua regime untuk memperkirakan parameter of Threshold Vector Error Correction Model. Berdasarkan Tabel 4 menunjukkan bahwa $p$-value pada pengujian supLM dengan nilai 0.016 lebih kecil dibandingkan nilai critical value-nya yakni 0.1 . Hal ini berarti harga beras di tingkat petani dan eceran memiliki threshold cointegration. Hasil uji TVECM memperoleh nilai threshold sebesar 0.092, yang membagi model menjadi dua regime yaitu regime satu (regime bawah) dan regime dua (regime atas) dengan persentase pengamatan pada masing-masing regime sebesar 6.3 persen dan 93.7 persen.

Nilai threshold mewakili nilai-nilai dari residual term dari cointegration regression yang menginisiasi perubahan pola respon terhadap adanya guncangan (penyimpangan dari keseimbangan jangka panjang). Nilai threshold sebesar 0.092 menunjukkan bahwa ketika deviasi dari rata-rata harga beras eceran dan petani pada keseimbangan jangka panjang melebihi 9.2 persen, maka harga akan menyesuaikan untuk mencapai keseimbangannya sehingga kedua harga beras tersebut memiliki hubungan kointegrasi dimana terjadi pada regime dua. Sebaliknya, ketika deviasi dari rata-rata harga beras eceran dan petani pada keseimbangan jangka panjang kurang dari 9.2 persen, maka tidak akan terjadi penyesuaian harga dan tidak ada integrasi pasar dimana terjadi pada regime satu.

Nilai ECT pada Tabel 5 menunjukkan bahwa nilai ECT harga beras eceran lebih besar daripada nilai ECT dari harga di tingkat petani. Hal ini menunjukkan bahwa harga beras eceran mengalami kenaikan lebih cepat dibandingkan dengan harga di tingkat petani. Sehingga proses penyesuaian harga yang dilakukan oleh harga beras eceran untuk mencapai keseimbangannya tidak efisien. Hal ini diduga bahwa biaya transaksi beras di tingkat eceran cenderung lebih besar dibandingkan biaya transaksi di tingkat petani, sehingga dapat dilihat masih belum efisiennya pasar beras di Indonesia. Sejalan dengan penelitian Rezitis dan reziti (2011) yang menginvestigasi penyesuaian nonlinear antara harga susu konsumen dan produsen di Yunani menggunakan threshold cointegration. Hasil menunjukkan bahwa hubungan kointegrasi diekspektasikan ketika keseimbangan harga konsumen menurun lebih dari 24.12 persen atau equilibrium relative markup lebih dari 62.74 persen. Dalam hal ini harga konsumen meningkat lebih cepat dari harga produsen untuk mengembalikan keseimbangan jangka panjang antara harga susu ditingkat produsen dan konsumen. Selain itu, Aprilia (2014) meneliti tentang pasar jagung di Indonesia, dimana diperoleh nilai threshold sebesar 0.208. Hasil dari penelitiannya juga menunjukkan bahwa harga di tingkat ritel meningkat lebih cepat daripada harga di tingkat petani. Penelitian (Laili F, Anindita R (2016) juga meneliti tentang transmisi harga yang terjadi antara harga gula dunia dengan harga gula domestik menunjukkan bahwa harga gula domestik mengalami kenaikan harga yang lebih cepat dibandingkan dengan harga gula dunia dengan memiliki threshold sebesar 0.942 . 


\section{KESIMPULAN}

Hasil estimasi nilai threshold yang diperoleh sebesar -0.092. Hal ini menunjukkan bahwa ketika deviasi harga beras eceran dan petani pada keseimbangan jangka panjangnya melebihi 9.2 persen, maka harga beras eceran akan menyesuaikan untuk mencapai keseimbangannya sehingga kedua harga beras tersebut memiliki hubungan kointegrasi. Sebaliknya, ketika deviasi harga beras kurang dari 9.2 persen, maka tidak akan terjadi penyesuaian harga dan tidak ada integrasi pasar. Harga beras di tingkat eceran mengalami kenaikan lebih cepat dibandingkan dengan harga beras di tingkat petani.

Berdasarkan nilai threshold yang diperoleh sebesar -0.092, dapat menjadi alternatif lain sebagai bahan pertimbangan bagi pemerintah untuk mengambil kebijakan. Ketika deviasi harga beras melebihi 9.2 persen maka pemerintah perlu melakukan intervensi misalnya dengan cara operasi pasar khusus. Selain itu perlu optimalisasi peran lembaga khususnya BULOG dalam stabilisasi harga beras, sehingga intervensi harga beras baik di tingkat petani maupun eceran akan lebih efektif.

\section{DAFTAR PUSTAKA}

Aprilia A (2014) Threshold Cointegration pada Pasar Jagung di Indonesia. Universitas Brawijaya.

Dodge E, G. S. (2012) Food Security and Price Stabilization in Indonesia: Analysis of Policy Responses. Cambridge (US): Harvard Kennedy School of Government.

F, Y. (2012) Analisa Integrasi Pasar dan Transmisi Harga Beras Petani-Konsumen di Indonesia. Universitas Indonesia.

Fitriani, F. (2017) 'Climate Changing Impact on Rice Production', Journal of Food System \& Agribusiness, 1(1), pp. 41-46. doi: 10.25181/jofsa.v1i1.82.

Fomby, T. B. and Blake, N. S. (1997) 'Threshold Cointegration', International Economic Review, 38(3), pp. 627-645.

Hansen, B. E. and Seo, B. (2002) 'Testing for two-regime threshold cointegration in vector errorcorrection models', Journal of Econometrics, 110(2), pp. 293-318. doi: 10.1016/S03044076(02)00097-0.

Laili F, Anindita R, S. B. (2016) 'Transmisi Harga Pasar Gula Rafinasi di Indonesia. Prosiding Seminar Nasional Pembangunan Pertanian', in Prosiding Seminar Nasional Pembangunan Pertanian.

[Pusdatin] Pusat Data dan Sistem Informasi Pertanian (2015) Outlook Komoditas Pertanian Subsektor Tanaman Pangan: Padi. Jakarta (ID).

Rezitis AN, R. I. (2011) 'Threshold Cointegration in the Greek Milk Market', Journal of International Food and Agribusiness Marketing, 23(3), pp. 231-246.

Sawit MH (2014) Arah dan Tantangan Baru Pembangunan Pertanian 2014-2019. Jakarta (ID): IAARD Press.

Vavra, P. and Goodwin, B. (2005) 'Analysis of price transmission along the food chain', (3), pp. 158.

Widarjono (2013) Ekonometrika Pengantar dan Aplikasinya Disertai Panduan Eviews. Yogyakarta (ID): UPP STIM YKPN. 